\title{
32. CROSS-LAMINATED AND GRADED INTERPILLOW LIMESTONES, SITE $562^{1}$
}

\author{
Leslie A. Reynolds and Brad K. Linsley, Department of Geology, University of South Carolina ${ }^{2}$
}

\begin{abstract}
Interpillow limestones were recovered from numerous cores of Leg 82. Limestones from Core 562-1, south of the Hayes Fracture Zone, display small-scale cross laminations composed of planktonic foraminiferal tests alternating with micrite. In nonlaminated portions of the limestones, graded bedding is evident. Foraminiferal species identified from thin sections date the limestones of Core 562-1 as early middle Miocene, approximately $16 \mathrm{Ma}$. This age corresponds with that determined for the lowermost sediments recovered at Site 562, which lie within $9 \mathrm{~m}$ of the interpillow limestones. The presence of undisturbed structures in the upper limestones may be the result of sediment void-infilling between pillow basalts, as opposed to a post-depositional intrusion of basalts into the carbonate sediments. Thus, the basalts have a minimum age of $16 \mathrm{Ma}$.
\end{abstract}

\section{INTRODUCTION}

The interaction of pelagic limestones and igneous rocks has been discussed in detail by Garrison (1974) who suggests that interpillow limestones were in fact recrystallized carbonate oozes and not inorganic precipitates. McKenzie and Kelts (1980) reported on the occurrence of interpillow limestones from Site 417D, Leg 51, and observed the progressive recrystallization of pelagic oozes. They concluded that basalt flows plunging into ponded carbonate oozes were responsible for the formation of these interpillow limestones. Limestones with high degrees of alteration were used in both studies.

The interpillow limestones recovered from Site 562 are distinct in that pelagic ooze preservation ranges from well-preserved, graded cross laminations to total recrystallization. The purpose of this study is to date the basalt flow biostratigraphically and discuss possible origins for interpillow limestone formation at Site 562.

\section{OCCURRENCE OF INTERPILLOW LIMESTONES AT SITE 562}

Cores 562-1 to 562-9 contain several scattered interpillow limestones, the largest of which is $4.0 \mathrm{~cm}$ in length. The limestones are found both welded to pillows of plagioclase phyric basalts and as individual clasts. Crosslaminated, foraminifer-rich limestones occur only in Core 1 , the upper part of which lies within $9 \mathrm{~m}$ of the sediment/basalt interface. Structureless limestones containing few foraminifers occur in Core 2 and are typical of those observed in deeper cores. In this study we focus on the Core 1 and Core 2 limestones that are representative of the entire interpillow limestone suite recovered at Site 562. The locations of these limestones and a description of their structural preservation are listed in Table 1.

\footnotetext{
${ }^{1}$ Bougault, H., Cande, S. C., et al., Init. Repts. DSDP, 82: Washington (U.S. Govt. Printing Office).

2 Address: Department of Geology, University of South Carolina, Columbia, South Carolina 29208.
}

Table 1. Interpillow limestone locations, Hole 562.

\begin{tabular}{lcc}
\hline $\begin{array}{c}\text { Core-Section, } \\
\text { Interval in cm } \\
\text { (Piece number) }\end{array}$ & $\begin{array}{c}\text { Sub- } \\
\text { bottom } \\
\text { depth } \\
(\mathrm{m})\end{array}$ & \multicolumn{1}{c}{ Description } \\
\hline $1-1,31-32(2 \mathrm{~A})$ & 241.32 & Homogeneous foraminifer-pellet \\
$1-2,17-19(2 \mathrm{~A})$ & 242.68 & grainstones \\
$1-2,96-99(5 \mathrm{~A})$ & 243.47 & \\
$1-2,130-131(7)$ & 243.81 & \\
& & \\
$1-3,108-110(5 \mathrm{~A})$ & 245.09 & Cross-laminated foraminifer- \\
$1-3,112-115(5 \mathrm{~B})$ & 245.14 & pellet grainstones \\
$1-4,1-4(1)$ & 245.53 & \\
& & \\
$2-2,20-22(4)$ & 251.71 & \\
$2-2,43-44(6)$ & 251.93 & Structureless limestones found in \\
$2-2,78-80(8 \mathrm{D})$ & 252.29 & contact with basalt pillows \\
$2-2,103-105(11)$ & 252.54 & \\
$2-3,84-86(4 \mathrm{~F})$ & 253.85 & \\
\hline
\end{tabular}

\section{DESCRIPTION}

The interpillow limestones found in Cores 1 and 2 are classified into three general groups based on their petrographic textures. The presence or absence of sedimentary structures and evidence of contact with cooling volcanogenic basalts are the main criteria for categorization. All samples examined have been classified as grainstones.

Cross-laminated, foraminifer-rich grainstones are found exclusively in Core 1 (Plate 1, Fig. 1). Three samples display alternating micrite and foraminifer-pellet laminations, range in color from white to buff, and have been replaced by sparry calcite cements. The cross laminations generally pinch out and may be truncated.

Foraminifer-pellet grainstones lacking cross laminations are also found in Core 1. Their bulk composition and color are similar in character to cross-laminated samples, although biogenic debris is more evenly dispersed. Calcite spar cements are dominant, and replacement of biogenic calcium carbonate and pore space is nearly complete.

The remaining limestones are structureless and in contact with basalt pillows. These grainstones are a darker 
yellow-buff, distinguishing them from the first two groups. Banded basalt and glass fragments are abundant.

\section{PLANKTONIC FORAMINIFERAL AGE DETERMINATIONS}

We place the Core 1 interpillow limestones within the planktonic foraminiferal zone, lower N9 (Blow, 1969), based on the presence of Globigerinoides sicanus (Plate 1, Fig. 2), Orbulina bilobata (Plate 1, Fig. 3), and Orbulina suturalis (Plate 1, Fig. 4), suggesting a maximum early middle Miocene age, approximately $16 \mathrm{Ma}$, for the sediments (Ryan et al., 1974). Globigerinoides trilobus, Globigerinoides immaturus, Globoquadrina venezuela$n a$, and Globorotalia scitula were also identified, supporting a $16 \mathrm{Ma}$ age.

Core 2 limestones contain fewer and smaller foraminifers than Core 1 limestones. The presence of Globigerinoides sicanus and the apparent absence of $O$. bilobata and $O$. suturalis may indicate a late early Miocene age for these older sediments.

\section{DISCUSSION}

According to Garrison (1974), interpillow limestones that exhibit cross laminations are the result of sediment infiltration into pre-existing pillow basalt voids. Pelagic sediments accumulate over basalt flows and occasionally spill into the voids as small graded turbidites. In contrast, basalt flows that intrude pre-existing sediments destroy sedimentary structures. The presence of crosslaminated graded limestones in Core 562-1 indicates the infiltration mode by redeposition (Garrison, 1974). Garrison also noted that fragmental volcanic debris is a common product of post-pillow or syn-pillow formation and submarine erosion. Both the absence of volcanic debris in Core 562-1, and the correlative ages of sediments above and below the sediment/basalt interface suggest that little submarine erosion occurred at this site immediately after the last volcanic episode. The presence of randomly oriented fecal pellets in Core 1 also indicates a lowenergy submarine environment.

Basalt flows below Core 1 may have intruded pre-existing sediments of the late early Miocene. The spar cements in Core 2 limestones are partly neomorphic, the result of pore-water cementation and heat-induced recrystallization (McKenzie and Kelts, 1980). In addition, a distinct sediment zone adjacent to pillow margins, approximately $1 \mathrm{~cm}$ thick, appears to be recrystallized (Plate 1, Fig. 5). The overall textural appearance of Core 2 limestones differs from the cross-laminated limestones of Core 1 (Plate 1, Fig. 6).

Core 1 and 2 limestones lack evidence of compaction, indicating that lithification and subsequent pore infilling was accomplished by early marine carbonate cements. Lower middle Miocene foraminiferal sediments are unlithified immediately above the uppermost basalts.

In conclusion, the analysis of Site 562 interpillow limestones has led to a minimum age placement of $16 \mathrm{Ma}$ on the last volcanic episode in this region. The presence of several cross-laminated and graded limestones containing key index fossil foraminifers and the absence of volcanic debris derived from submarine erosion support this age placement.

\section{ACKNOWLEDGMENTS}

We wish to thank Drs. Dorothy Echols, Robert Thunell, and Michael Arthur for their assistance and helpful comments. We are also most grateful to Ric Pantonial for photographic work and to Eric Tappa for his assistance and helpful comments.

\section{REFERENCES}

Blow, W. H., 1969. Late middle Eocene to Recent planktonic foraminiferal biostratigraphy. In Brönniman, P., and Renz, H. H. (Eds.), Proc. First Int. Conf. Plankt. Microfossils: Leiden (E. J. Brill), 1: 199-421.

Garrison, R. E., 1974. Radiolarian cherts, pelagic limestones and igneous rocks in eugeosynclinal assemblages. Spec. Publ. Int. Assoc. Sedimentol., 1:367-399.

McKenzie, J. A., and Kelts, K. R., 1980. A study of interpillow limestones from the $M$-Zero anomaly, Deep Sea Drilling Project, Leg 51, Hole 417D. In Donnelly, T., Francheteau, J., Bryan, W., Robinson, P., Flower, M., Salisbury, M., et al., Init. Repts. DSDP, 51, 52, 53, Pt. 2: Washington (U.S. Govt. Printing Office), 753-766.

Ryan, W. B. F., Cita, M. B., Rawson, M. D., Burkle, L. H., and Saito, T., 1974. A paleomagnetic assignment of Neogene stage boundaries and the development of isochronous datum planes between the Mediterranean, the Pacific, and Indian oceans in order to investigate the response of the world ocean to the Mediterranean "Salinity Crisis." Riv. Ital. Paleontol., 80(4):631-688.

Date of Initial Receipt: 16 May 1983

Date of Acceptance: 1 May 1984 

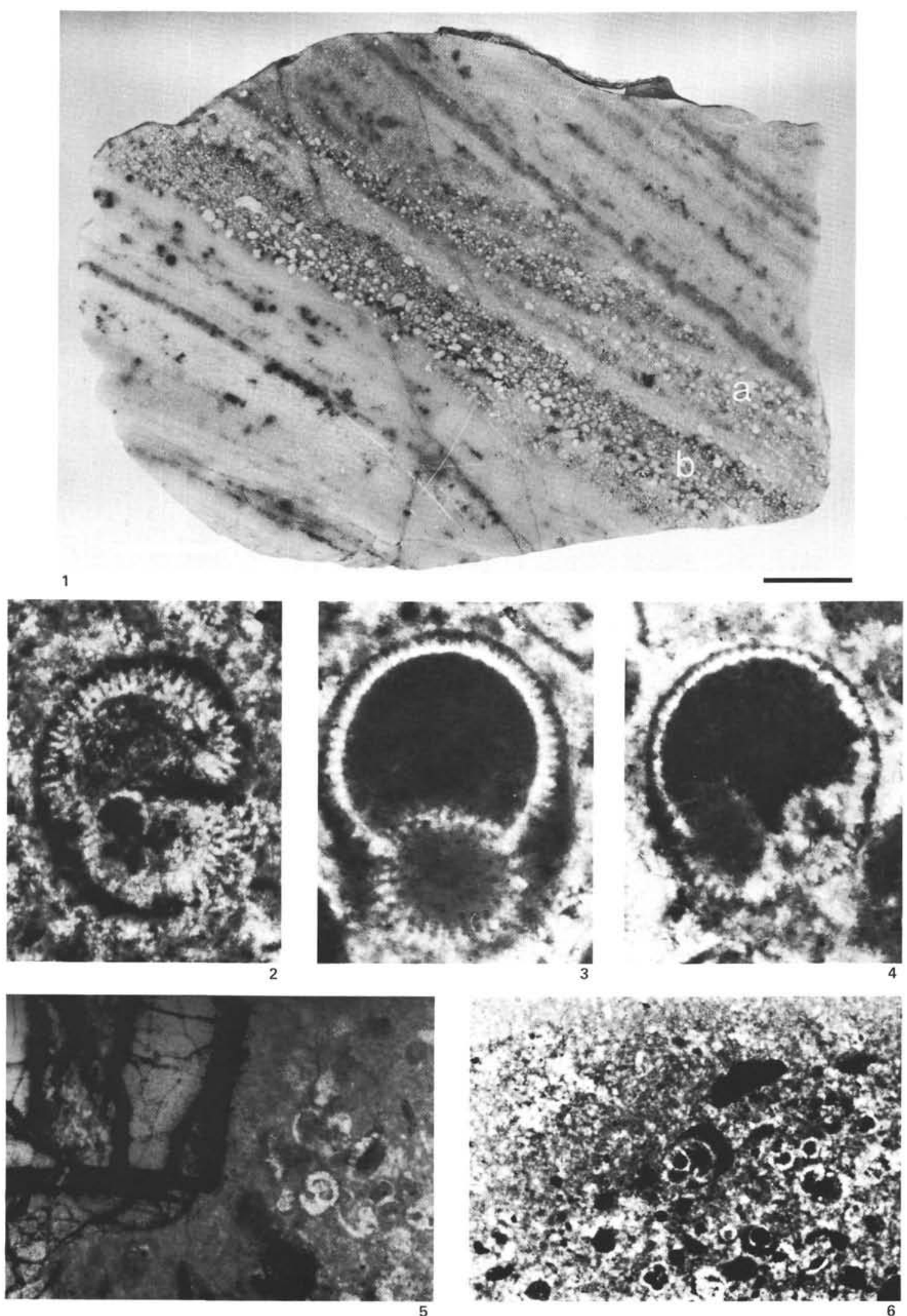

Plate 1. 1, 3, 4, 6. Sample 562-1-3, 108-110 cm (piece 5A), (1) Cross-laminated (A) and graded (B) interpillow limestone; note truncation of crosslaminations; scale bar $=0.5 \mathrm{~cm}$, (3) Orbulina bilobata thin section view, $\times 110$, (4) Orbulina suturalis thin-section view, $\times 110,(6)$ Cross-lamination boundary between micrite and foraminifer-rich laminations. 2. Sample 562-1-3, 112-115 cm (piece 5B), Globigerinoides sicanus, thin-section view, $\times 110$. 5. Contact of pillow basalt glass with calcareous sediments; note neomorphic region (McKenzie and Kelts, 1980 ), $\times 80$. 